\title{
LIFE HISTORY OF THE TAPEWORM KHAWIA SINENSIS HSÜ, 1935, A CARP PARASITE, IN THE POND DRAŽSKÝ SKALIČANY NEAR BLATNÁ, CZECHOSLOVAKIA
}

\author{
T. SCHOLZ, V. SPETA ${ }^{1}$ and J. ZAJfCEK ${ }^{2}$ \\ Institute of Parasitology Czechoslovak Academy of Sciences, 37005 Ceské Budějovice \\ ${ }^{1}$ District Veterinary Administration, 38601 Strakonice \\ ${ }^{2}$ State Veterinary Administration - Regional Administration, 37138 České Budějovice
}

Received November 11, 1988

\begin{abstract}
Scholz T., V. Špeta, J. Zajíček: Life History of the Tapeworm Khawia sinensis Hsü, 1935, a Carp Parasite in the Pond Dražský Skaličany near Blatná, Czechoslovakia. Acta vet. Brno, 59, 1990: 51-63.

The life cycle of the tapeworm Khawia sinensis was studied on the basis of examination of 280 stock carp (Cyprinus carpio - K 1-2)) and 9671 water oligochaetos of the families Tubificidae and Naididae from the pond Dražský Skaličany near Blatná from May 1987 to July 1988. The results showed the presence of the parasite in the pond throughout the year; the highest infestation of the carp was observed in late spring (May) and was followed by subsequent gradual departure particularly of gravid $K$. sinensis from the hosts at the end of June and at the beginning of July. Reinfection of the fish began in mid July. $K$. sinensis with eggs were found throughout the observation period. After dehelminthization the number of infested carp decreased but rose again within a month in consequence of reinfections. The intermediate host of $K$. sinensis in Czechoslovakia was ascertained for the first time under natural conditions. In the locality under study it was Tubifex tubifex (probably the exclusive intermediate host of $K$. sinensis there) which is not the dominant species in the pond compared with members of the genus Limnodrilus. $K$. sinensis larval stages can survive in intermediate hosts over winter when the pond is drained and its bottom is exposed to frost. Disinfection of the bottom with quicklime produced a considerable decrease in the incidence of $T$. tubifex, but a small proportion of $K$. sinensis larvae survived in these intermediate hosts and became the source of infection for the new stock in spring 1988.
\end{abstract}

Tapeworm Khawia sinensis, carp, tubificids, life history, seasonal dynamics of incidence and maturation

The tapeworm Khawia sinensis Hsü, 1935 (Cestoda: Caryophyllidea), a carp parasite, has been spreading considerably in many ponds over a large area of Czechoslovakia during the last decade. A similar situation exists in a number of other countries where this originally non-European tapeworm species has become quite common. As the disease produced by $K$. sinensis has a major economic effect and may even result in death loss in carp (Kulakovskaya 1963, Shcherban 1965, Prouza and Tesarčik 1977 a. o.) this parasite has received considerable attention (Kulakovskaya and Krotas 1961, Kulakovskaya et al. 1965, Sapozhnikov 1970, 1971, 1972, Lozinska-Gabska 1981 a. o.). Most studies along this line recorded the incidence of $K$. sinensis in new localities and were focussed mainly on the possibilities of prophylaxis. Therefore some aspects of the biology and epizootiology of this tapeworm of major economic importance still remain undisclosed. No data at all are available on the biology of $K$. sinensis in Czechoslovak ponds because previous studies in this country by Tesarćík and Prouza (1977), Prouza and Tesarčík (1977) and Prouza (1982) were either concerned with the therapy of infected carp or were based on the results of mainly Soviet investigators. 
For oür study we chose the pond Dražský Skaličany because of the possibility of long-term collection of fish samples and because the infestation of carp with $K$. sinensis in this pond was rather high at the beginning of our observations. Thanks to the understanding of the personnel of the respective branch plant dehelmithization of the fish was carried out as late as one month before fishing. In the aforementioned pond we studied the occurrence of $K$. sinensis both in definitive hosts (carp) and in potential intermediate hosts - water oligochaets of the families Tubificidae and Naididae.

\section{Materials and Methods}

The pond Dražský Skaličany in which our investigations were conducted lies 437 metres above sea level about 3 kilometres north-east of Blatná (catchment area of the river Lomnice). Its area is 6.1 hectares and its maximum depth is 2 metres. At the time of our research the stock consisted of stock carp $\left(35000 \mathrm{~K}_{1}\right.$ ) originating from a fingerling pond, Dalina near Blatná. The fish were caught by means of cast nets, mostly after the fish were fed. In 1987 carp samples were obtained at approximately 2-week intervals from mid May to mid November (see Table 1). A total of 193 carp were examined. In October 1987 (23 Oct.) dehelminthization was carried out with Taenifugin carp in doses recommended by the manufacturer. In February 1988 the pond bottom was disinfected with quicklime in doses of 3000 and $7500 \mathrm{~kg}$. In 1988 three further fish samples were taken: 30 carp were obtained upon fishing a fingerling pond, Stárka, the stock of which was transferred to the pond Dražský Skaličany and a total of 57 carp were obtained for examination from the pond Dražský Skaličany on two further occasions. The objective of these collection was to obtain information on the occurrence of $K$. sinensis in the locality after the pond was drained and disinfected and a new stock was planted.

The catch was transported alive to the Institute of Parasitology Czechoslovak Academy of Sciences, Ceské Budějovice, and dissected there mostly the same day or the next day at the latest. The location of $K$. sinensis in the gut was recorded and the parasites were then removed from the gut and transferred to water. After relaxation in a refrigerator they were fixed with $4 \%$ formalin under pressure. For assessment of their sexual maturity the majority of $K$. sinensis recovered (281 specimens) were stained with Schuberg's carmine, dehydrated with increasing concentrations of alcohol, cleared with carbolxylol and mounted in Canada balsam. They were divided into the following four groups: Group I (juvenile tapeworms) - gonads, except genital primordium, not developed; Group II (maturing tapeworms) - gonads in the process of development; Group III (mature tapeworms) - gonads developed, without eggs; Group IV (gravid tapeworms) - eggs in uterus. In each fish sample the per cent proportions of $K$. sinensis in the four groups were calculated and seasonal dynamics of the maturation of the parasite was assessed. To obtain information on the location of the parasite in the gut of hosts and its seasonal changes the gut was divided into 4 parts: anterior part down to the first intestinal loop, henceforward referred to here as "widened gut", and the anterior, middle and posterior thirds of the remaining portion of the gut. Also in this case the per cent proportions of $K$. sinensis found in the aforementioned parts of the gut were calculated in each evaluated fish sample.

The degree of infestation of the fish was characterized using the following terms (Margolis et al. 1982): prevalence (per cents hosts infected out of total number of fish examined in the sample), mean intensity of infection (mean number of parasites per infected fish), minimal and maximal intensity of infection (the lowest and the highest number of parasites in a host).

Together with the fish, mud samples containing oligochaets were taken from the pond to find intermediate hosts of $K$. sinensis. The mud was obtained from the bottom with an Eckman-Birg grab over an area of $225 \mathrm{sq}$. cm. The samples were taken from depths of 180 to $200 \mathrm{~cm}$ at the site where the mud layer was highest (about 25 metres distant from the outlet). The number of mud collections during the observation period varied (mostly 5 collections in 1987 and 10 collections in 1988). The mud obtained was sifted through 0.50 to $0.75 \mathrm{~mm}$ mesh-nets directly on the spot and then examined for the presence of tubificids and naidids with a microscope in the laboratory. Species of the genus Limnodrilus were determined only in adult specimens. The determination was carried out according to Hrabě (1981). 


\section{Results}

Incidence of $K$. sinensis in the Definitive Host

In 78 out of the 193 carp examined in 1987 a total of $303 \mathrm{~K}$. sinensis were found (prevalence, $40.4 \%$; mean intensity, 3.9). Values for the intensity of infection ranged from 1 to 36 parasites. A survey of the infestation of carp in 1987 together with the results of examination of three fish samples obtained in 1988 is shown in Table 1.

Table 1

Survey of carp (Cyprinus carpio $-K_{1-2}$ ) examined from the-pond Dražský Skaličany and their infeatation with the tapeworm Khawia sinensis

\begin{tabular}{|c|c|c|c|c|c|c|}
\hline \multirow{2}{*}{ Date } & \multirow{2}{*}{$\begin{array}{l}\text { Water } \\
\text { temp. } \\
\left({ }^{\circ} \mathrm{C}\right)\end{array}$} & \multicolumn{2}{|c|}{ No. of carp } & \multirow{2}{*}{$\begin{array}{c}\text { Prevalence } \\
(\%)\end{array}$} & \multirow{2}{*}{$\begin{array}{c}\text { No. of } \\
\text { tapeworms }\end{array}$} & \multirow{2}{*}{ 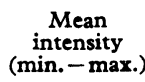 } \\
\hline & & examined & infected & & & \\
\hline $\begin{array}{r}1987 \\
13.5 . \\
26.5 . \\
17.6 . \\
29.6 . \\
16.7 . \\
30.7 . \\
11.8 . \\
25.8 . \\
8.9 . \\
22.9 . \\
7.10 . \\
20.10 . \\
2.11 . \\
16.11 .\end{array}$ & $\begin{array}{r}15 \\
16 \\
17 \\
23 \\
26 \\
18 \\
17 \\
22 \\
17 \\
20 \\
14 \\
11 \\
7 \\
3\end{array}$ & $\begin{array}{r}1 \\
8 \\
15 \\
18 \\
16 \\
15 \\
16 \\
16 \\
14 \\
18 \\
5 \\
16 \\
15 \\
20\end{array}$ & $\begin{array}{r}1 \\
5 \\
6 \\
0 \\
8 \\
8 \\
8 \\
9 \\
9 \\
13 \\
13 \\
2 \\
5 \\
1 \\
4\end{array}$ & $\begin{array}{r}- \\
4 \\
40 \\
50 \\
53 \\
50 \\
56 \\
57 \\
72 \\
- \\
31 \\
7 \\
20\end{array}$ & $\begin{array}{r}7 \\
56 \\
16 \\
70 \\
17 \\
36 \\
32 \\
22 \\
26 \\
3 \\
8 \\
4 \\
6\end{array}$ & $\begin{array}{c}11(1- \\
3(1-32) \\
3(1-6) \\
9(1-36) \\
2(1-4) \\
5(1-13) \\
4(1-9) \\
3(1-5) \\
2(1-5) \\
-(1-2) \\
2(1-3) \\
-(4) \\
2(1-2)\end{array}$ \\
\hline Total & - & 193 & 78 & 40 & 303 & $3,9(1-36)$ \\
\hline $\begin{array}{l}\left.12.4 .^{*}\right) \\
14.6 . \\
1.7 .\end{array}$ & $\begin{array}{l}10 \\
19 \\
20\end{array}$ & $\begin{array}{l}30 \\
26 \\
31\end{array}$ & $\begin{array}{r}5 \\
10 \\
4\end{array}$ & $\begin{array}{l}17 \\
38 \\
13\end{array}$ & $\begin{array}{r}6 \\
21 \\
14\end{array}$ & $\begin{array}{l}1(1-2) \\
2(1-4) \\
4(1-9)\end{array}$ \\
\hline
\end{tabular}

*) Carp from the fingerling pond Stárka before their release into the pond Dražský Skaličany

\section{Food of Carp Examined}

With the exception of two fish of 25 August 1987 the gut of all carp was filled with food. The gut contents consisted of feed, mud with benthos residues, mainly chironomid larvae or corixids, plankton crustaceans, particularly Cladocera, and in autumn also Copepoda, paste-like chyme or plant residues. Besides the food that was found in a large proportion of fish examined from mid June to the beginning of November a predominance of plankton crustaceans was detected in 1987 in the food of carp caught in spring, whereas benthos animal residues more or less prevailed in summer and autumn. Mud with benthos residues was found in the gut contents of carp most frequently in mid July, in August and the end of September. On the whole, benthos residues were found in the gut of 72 carp. i. e. in $37 \%$ of the fish. Tubificidae were found only in the gut contents of a fish examined at the beginning of October. Examination of its gut contents detected about 50 specimens of the genus Limnodrilus ( $L$. helveticus, $L$. hoffmeisteri, $L$. claparedeanus), most of which were still alive. 


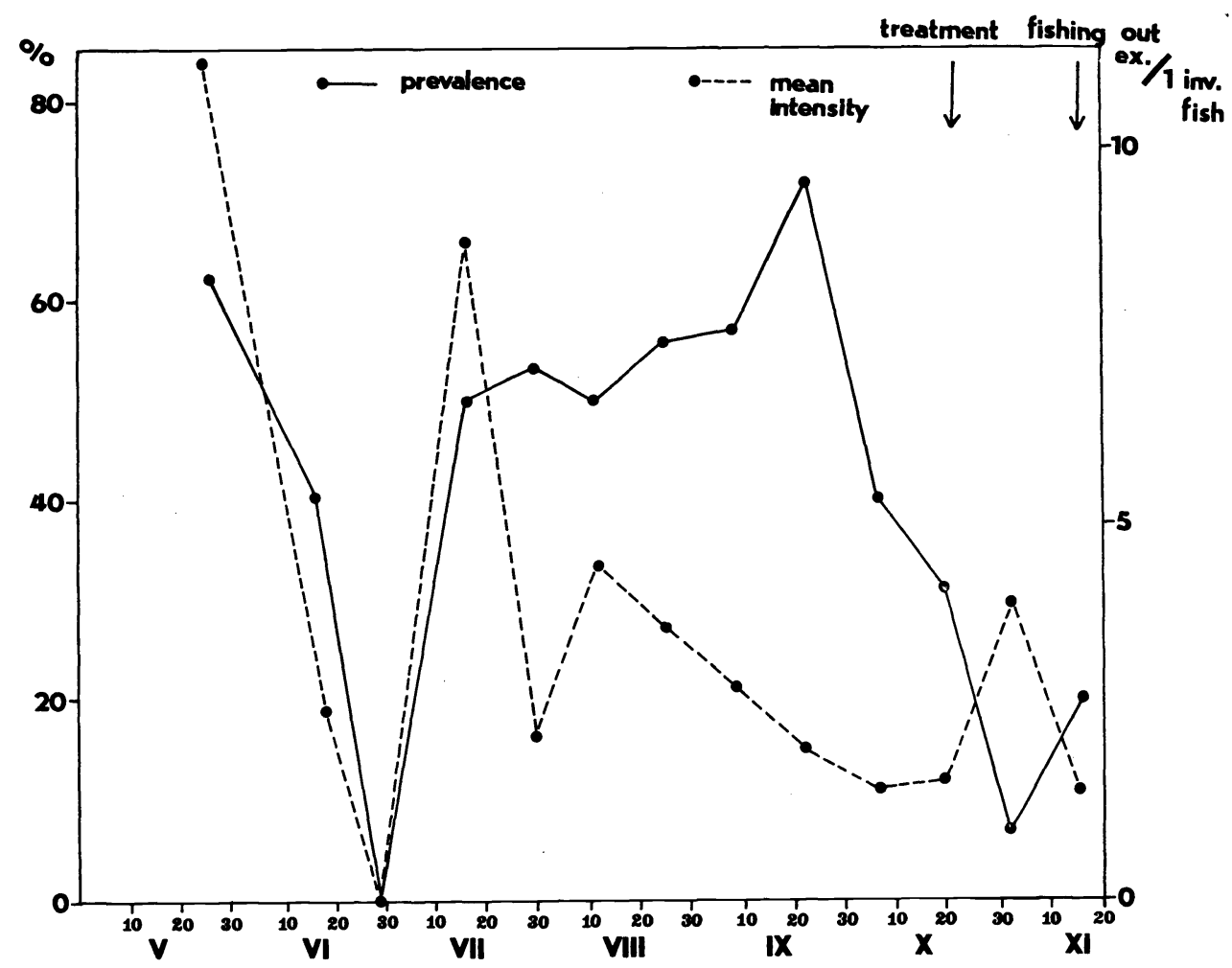

Fig. 1. Seasonal dynamics in the incidence of Khawia sinensis in stock carp (Cyprinus carpio $-\mathrm{K}_{1-2}$ ) from the pond Dražský Skaličany near Blatná in 1987

Seasonal Dynamics of the Incidence of $K$. sinensis

Data on seasonal changes in the infestation of carp from the pond Dražský Skaličany in 1987 are shown in Table 1 and jFig. 1 . In $1988 K$. sinensis were found in all three fish samples (Table 1).

\section{Seasonal Dynamics of $K$. sinensis Maturation}

To assess the seasonal dynamics of $K$. sinensis maturation examined in 1987 a total of $281 \mathrm{~K}$. sinensis were evaluated. Of these, $118(42 \%)$ specimens were juvenile tapeworms (Group I), $68(24 \%$ ) were maturing tapeworms (Group II), $33(12 \%)$ were mature tapeworms (Group III) and $62(22 \%)$ were gravid tapeworms (Group IV). Per cent contributions of the four groups to the fish samples obtained during the period under study are shown in Fig. 2.

In the carp examined in 1988 all four groups were represented and the respective counts were as follows: 12 April (pond Stárka) - out of $6 \mathrm{~K}$. sinensis recovered 5 were mature and 1 was gravid; 14 June (pond Dražský Skaličany) out of $8 \mathrm{~K}$. sinensis 6 were juvenile, 1 was maturing and 1 was gravid; 1 July (pond Dražský Skaličany) - out of $14 \mathrm{~K}$. sinensis 2 were maturing, 4 were mature and 8 were gravid. 


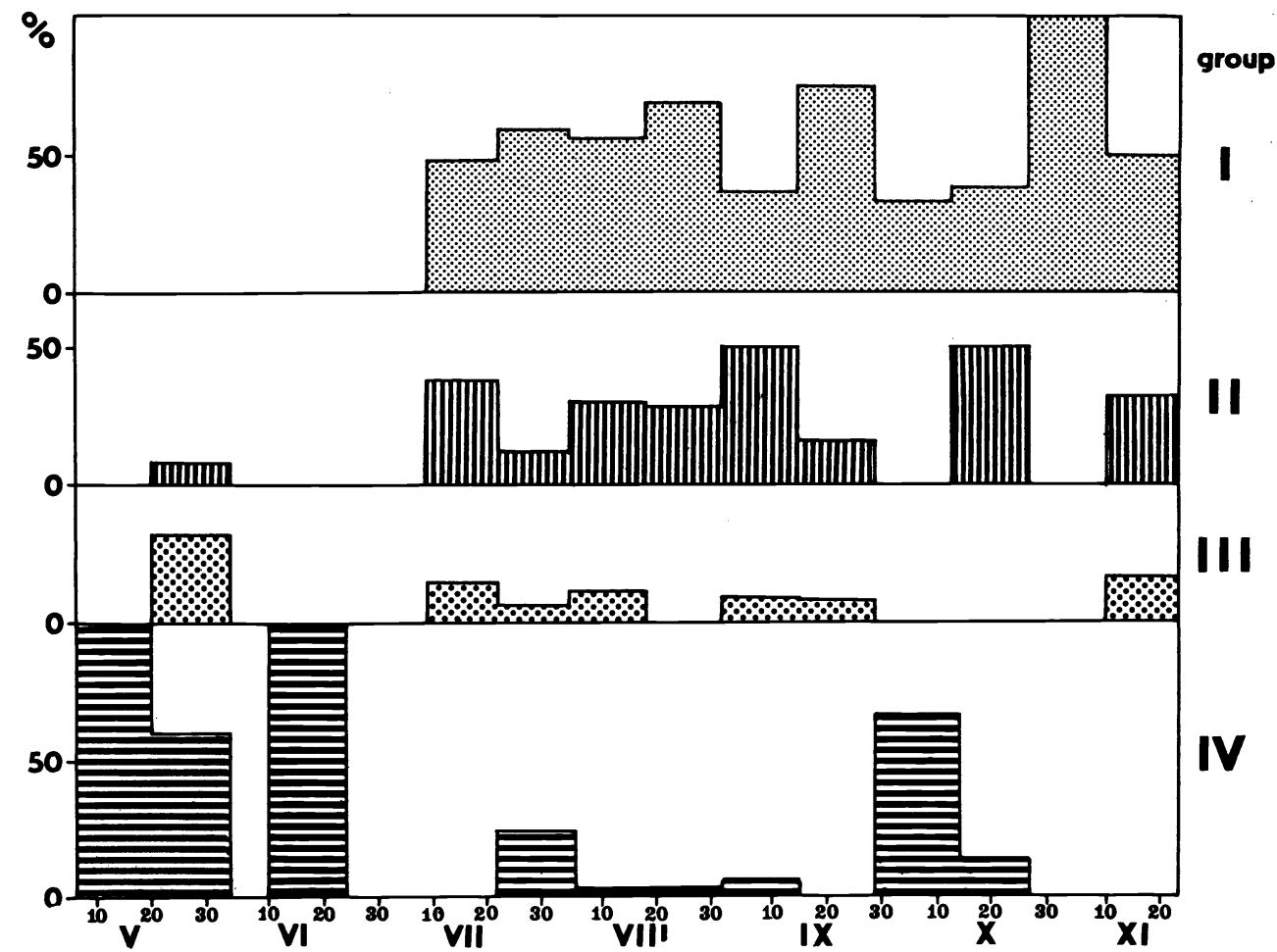

Fig. 2. Seasonal dynamics in the maturation of Khawia sinensis in stock carp (Cyprinus carpio $\mathrm{K}_{1-2}$ ) from the pond Dražský Skaličany near Blatná in 1987 (for division of $K$. sinensis into groups see Materials and Methods)

\section{Location of $K$. sinensis in the Gut of Hosts}

The parasite was found in all parts of the gut of carp but its distribution was uneven: $222(73 \%) \mathrm{K}$. sinensis were found in the "widened gut", particularly in its posterior portion before the first intestinal loop, $63(21 \%) K$. sinensis in the anterior third, $13(4 \%)$ in the middle third and $5(2 \%)$ in the posterior third of the remaining part of the gut. Seasonal changes in the location of $K$. sinensis in the indivudal parts of the gut are shown in Fig. 3.

\section{Incidence of $K$. sinensis in the Intermediate Host}

A total of 9671 oligochaetopods of the families Tubificidae and Naididae from 27 collections were examined for the possible presence of $K$. sinensis larval stages between May 1987 and June 1988. A survey of the results is presented in Table 2. $K$. sinensis larvae were found only in tubificids of the species Tubifex tubifex (Müll.). A survey of infestation of these tubificids together with the dimensions and location of $K$. sinensis larvae is shown in Table 3. The degree of their development as recorded during the period under study was as follows: the smallest larvae were found at the beginning of the sampling program (May and June 1987) and 


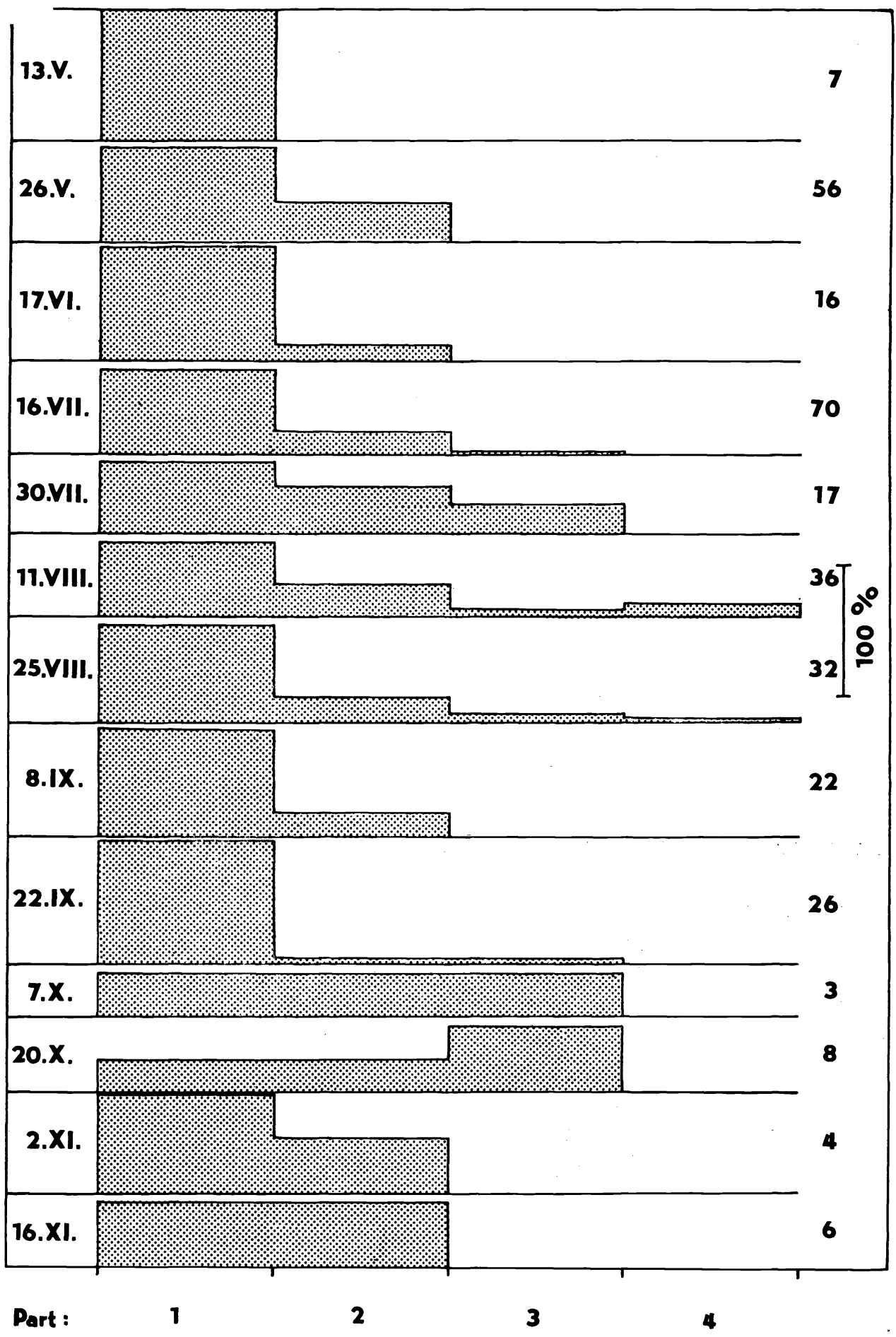


Table 2

Survey of oligochaets examined from the pond Dražský Skaliðany

\begin{tabular}{|c|c|c|c|c|c|c|c|c|}
\hline \multirow{2}{*}{ Date } & \multicolumn{5}{|c|}{ Tubificidae } & \multicolumn{2}{|c|}{ Naididae } & \multirow[b]{2}{*}{ Total } \\
\hline & $1 *)$ & 2 & 3 & 4 & Total & 5 & 6 & \\
\hline $\begin{array}{r}1987 \\
13.5 . \\
26.5 . \\
17.6 . \\
29.6 . \\
16.7 . \\
30.7 . \\
11.8 . \\
25.8 . \\
8.9 . \\
22.9 . \\
7.10 . \\
20.10 . \\
2.11 . \\
16.11 .^{1)} \\
8.12 .\end{array}$ & $\begin{array}{r}5 \\
17 \\
13 \\
10 \\
4 \\
7 \\
20 \\
38 \\
52 \\
95 \\
101 \\
117 \\
97 \\
6 \\
13\end{array}$ & $\begin{array}{l}1 \\
1 \\
- \\
- \\
\overline{1} \\
- \\
\overline{2} \\
1 \\
1 \\
\overline{1} \\
\overline{1}\end{array}$ & $\begin{array}{r}6 \\
7 \\
9 \\
4 \\
19 \\
5 \\
2 \\
18 \\
10 \\
6 \\
8 \\
5 \\
21 \\
13 \\
87\end{array}$ & $\begin{array}{r}31 \\
27 \\
30 \\
57 \\
26 \\
14 \\
102 \\
268 \\
407 \\
474 \\
364 \\
460 \\
399 \\
63 \\
314\end{array}$ & $\begin{array}{r}43 \\
52 \\
52 \\
71 \\
49 \\
26 \\
125 \\
324 \\
469 \\
577 \\
474 \\
583 \\
517 \\
82 \\
415\end{array}$ & $\begin{array}{l}\overline{-} \\
- \\
- \\
\overline{-} \\
\overline{2} \\
\overline{-} \\
\overline{1} \\
86 \\
3 \\
-\end{array}$ & $\begin{array}{l}\bar{z} \\
= \\
= \\
= \\
= \\
= \\
\overline{60} \\
= \\
-\end{array}$ & $\begin{array}{l}- \\
- \\
- \\
- \\
\overline{2} \\
\overline{-} \\
\overline{-} \\
1 \\
146 \\
3 \\
-\end{array}$ \\
\hline $\begin{array}{c}1988 \\
7.1 . \\
19.1 . \\
2.2 . \\
\left.16.2 .^{2}\right) \\
1.3 . \\
14.3 . \\
29.3 . \\
\left.12.4 .^{3}\right) \\
26.4 . \\
10.5 . \\
24.5 . \\
14.6 .\end{array}$ & $\begin{array}{r}62 \\
19 \\
23 \\
41 \\
2 \\
11 \\
84 \\
1 \\
11 \\
- \\
5 \\
4\end{array}$ & $\begin{array}{l}-1 \\
-1 \\
- \\
- \\
- \\
- \\
- \\
-\end{array}$ & $\begin{array}{r}423 \\
193 \\
204 \\
132 \\
27 \\
76 \\
140 \\
105 \\
130 \\
47 \\
57 \\
28\end{array}$ & $\begin{array}{l}764 \\
416 \\
281 \\
280 \\
117 \\
281 \\
575 \\
113 \\
340 \\
203 \\
236 \\
225\end{array}$ & $\begin{array}{r}1250 \\
628 \\
509 \\
453 \\
146 \\
368 \\
799 \\
219 \\
481 \\
250 \\
300 \\
257\end{array}$ & $\begin{array}{l}- \\
= \\
= \\
= \\
= \\
= \\
- \\
- \\
-\end{array}$ & $\begin{array}{l}\overline{-} \\
= \\
= \\
= \\
\overline{-} \\
= \\
= \\
-\end{array}$ & $\begin{array}{l}- \\
- \\
- \\
- \\
- \\
- \\
- \\
-\end{array}$ \\
\hline Total & 858 & 12 & 1782 & 6867 & 9519 & 92 & 60 & 152 \\
\hline
\end{tabular}

Explanations: *) 1 - Tubifex tubifex, 2 - Limnodrilus udekemianus, 3 - adult Limnodrilus spp., 4 - juvenile Limnodrilus spp., 5 - Dero spp., $6-$ Nais pseudoobtusa $\left.;^{1}\right)$ - fishing out, $\left.{ }^{2}\right)-$ bottom liming, ${ }^{3}$ ) - plantation of new stock carp.

infective procercoids were first recovered in July. After the pond bottom was disinfected with quicklime in mid February no $K$. sinensis larval stages, except 4 specimens at the end of March, were found till the end of the observation period (June 1988). In these samples, however, T. tubifex counts were very low (11 specimens at the highest).

\section{Discussion}

The results of observations on the incidence of $K$. sinensis in intermediate and definitive hosts from the pond Dražský Skaličany enable us to reconstruct the life history of this parasite in the pond under study in 1987. The high level of infestation of the carp in spring shortly after their transference from the fingerling pond Dalina was probably the result of their infection contracted in the fingerling pond in autumn of the previous year. After the carp were transferred to the pond Dražský Skaličany $K$. sinensis became sexually mature in spring and began to produce

Fig. 3. Seasonal changes in the location of Khawia sinensis in the gut of stock carp (Cyprinus carpio - $\mathrm{K}_{1-2}$ ) from the pond Dražský Skaličany near Blatná in 1987. Portions of the gut: (1) "widened gut", (2) anterior third, (3) mid third, (4) posterior third of the remaining gut portion (see Materials and Methods) 
Table 3

Survey of the infestation of Tubifex tubifex with Khawia sinensis larvae

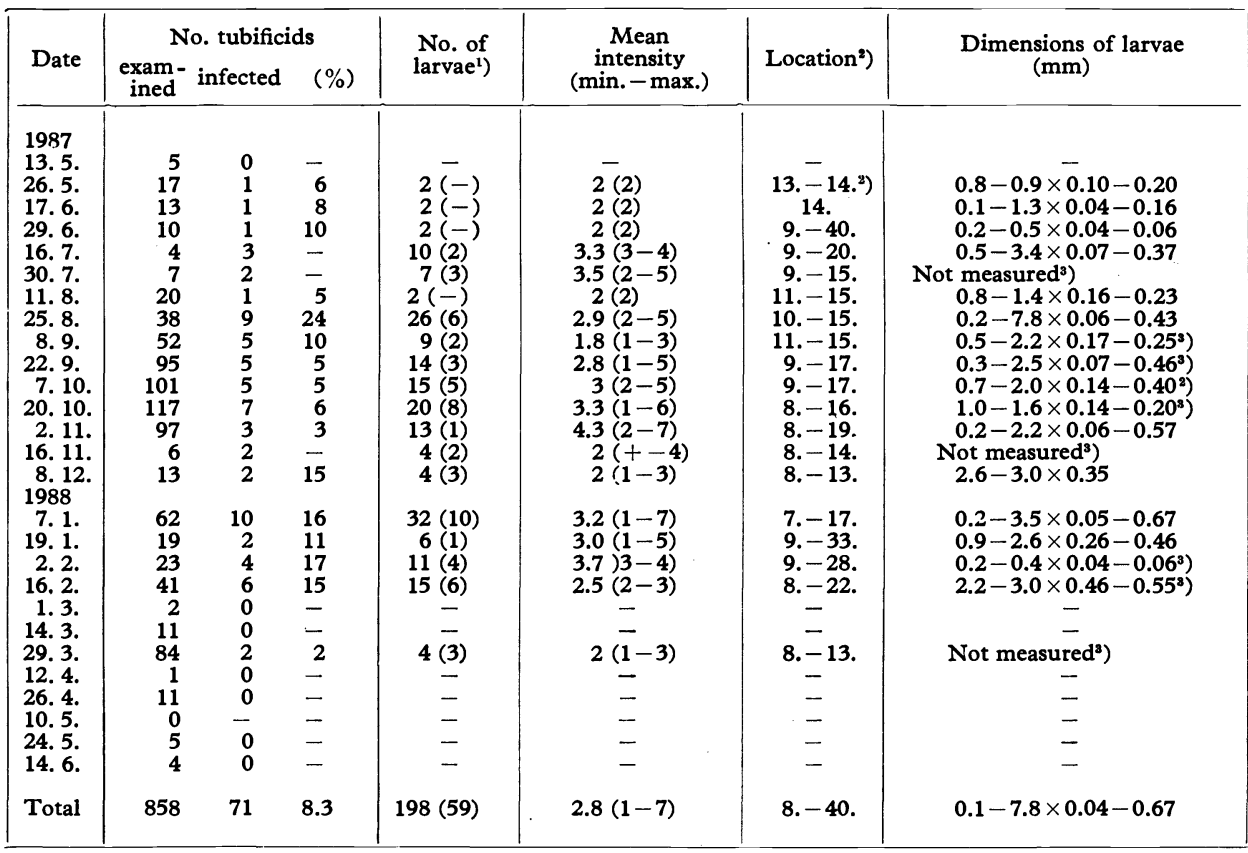

Explanations: 1) - No. of procercoids in brackets; 2) body segments of tubificids; 3) - procercoids used for experimental infection of fish (Scholz 1988)

eggs. This appears from the high proportion of gravid tapeworms in samples collected during this period.

In eggs released by $K$. sinensis in late spring and at the beginning of June oncospheres developed in the bottom of the pond within 3 to 4 weeks. After ingestion of these oncospheres-containing eggs by Tubifex tubifex infective procercoids developed in the intermediate hosts during a few (about 6 to 8) weeks, i. e. at the turn June-July. New infections of the carp with these procercoids occurred from the beginning of July to the autumn 1987. This appears from the fact that during this period tubificids were found to contain fully developed procercoids and juvenile tapeworms were first recovered from the gut of the carp. These young tapeworms originated presumably from a very recent infection, judging from our previously published data on the development of $K$. sinensis in the definitive host within 1 to 2 weeks of infection (S cholz 1988).

No juvenile $K$. sinensis, however, were recovered in spring and early summer 1987. Two explanations of this absence of young tapeworms can be offered: (1) The parasite was introduced in the pond Dražský Skaličany with the planting of the fish in spring 1987. Regular veterinary inspections had previously detected the incidence of $K$. sinensis in this pond for the last time in spring 1985. Upon transference of the fish from the fingerling pond Dalina in spring 1987, on the other hand, $K$. sinensis were recovered from $33 \%$ of the carp examined at an intensity of 1 to 3 specimens. These facts together with the findings of gravid parasites shortly after the fish were planted (in May) and the absence of procercoids from 
tubificids at this time support the afore-mentioned hypothesis. (2) Another possible explanation of the absence of juvenile tapeworms in late spring and in June might be the composition of carp food. In spring stock carp feed mainly, and occasionally even exclusively, on plankton and it is only in late spring that the fish begin gradually to consume benthos, i. e. also tubificids. This hypothesis is supported by the finding of a small number of carp ( 4 out of 42) with benthos residues in the gut upon examination in May and June and by the fact that the first findings of juvenile tapeworms in the fish from mid July were accompanied by an increased proportion of carp (11 out of 16 carp examined) having benthos residues in the gut. Also in the carp examined in summer and early autumn, i. e. at the time that juvenile tapeworm counts were high, the findings of benthos residues in the gut were very frequent. The solitary finding of tubificids in the gut can be accounted for by the fact that these oligochaets are decomposed in the fish gut very rapidly (within a few hours) and afterwards can be detected only under a microscope (Kennedy 1969). However, the presence of chironomid larvae and possibly the residues of other benthic animals provide indirect evidence for the consumption of tubificids because the contribution of tubificids to benthos in the pond Dražský Skaličany is high (the ratio of tubificids to chironomid larvae in the mud samples was $3.9: 1$ ).

The highest infestation of the carp was recorded in May, similarly to our previous observations on two-year-old fish from the pond Naděje near Lomnice nad Lužnicí (Scholz 1988). Likewise Sapozhnikov (1970) reported the highest infestation of stock carp in May and June. This investigator also found a marked decrease in the numbers of both infested fish and tapeworms in July, which is in keeping with our observations. Kulakovskay a (1963), on the other hand, reported that the incidence of $K$. sinensis in stock carp peaked in autumn. Presumably these differences reflect the differences in ecological conditions in different localities. Moreover, treatments such as supplementary feeding pond fertilization and liming, and fish dehelminthization exert major effects on the life cycle of the parasite in each locality.

At the end of June 1987 no $K$. sinensis were recovered from any of the fish examined. One of possible explanations, the hypothesis of a direct effect of incrased water temperature on premature departure of tapeworms from the gut of hosts, is refuted by our findings of a total of $70 \mathrm{~K}$. sinensis in $50 \%$ of the carp from the pond Dražský Skaličany examined in mid July 1987, at which time the water temperature $30 \mathrm{~cm}$ below the level reached $26^{\circ} \mathrm{C}$. Also the findings of $K$. sinensis in the carp examined at the beginning of July and the results of an experiment with $K$. sinensis survival in fish at $21^{\circ} \mathrm{C}$ to $22^{\circ} \mathrm{C}$ (S cholz 1988) provide further evidence against the afore-mentioned hypothesis. In our view, the departure of $K$. sinensis from fish in late spring is influenced by high water temperature only indirectly in"that higher temperatures accelerate sexual development of the parasite culminating in egg production and subsequent departure of gravid tapeworms from the body of hosts. The sample of $K$. sinensis found in the carp in mid June consisted en tierely of gravid tapeworms.

Before fishing out the pond Dražský Skaličany in 1987 the fish were dehelminthized prior to their transfer to a storage pond. In consequence, the infestation of the carp decreased but it was as early as one month after the medication that the parasite was found in the gut of $20 \%$ of the fish examined. This suggests that the fish may have become reingected soon after their dehelmithization. This hypothesis is fully supported by the findings of juvenile $K$. sinensis in November. 
The afore-mentioned reinfections are made possible by the presence of infective $K$. sinensis procercoids in tubificids at the bottom of the pond, a view confirmed also by our observations of the incidence ov $K$. sinensis larval stages in the intermediate hosts.

Our examination of water oligochaets from the bottom of the pond under study revealed the parasite only in tubificids of the species Tubifex tubifex. The identity of these larvae was confirmed by successful experimental infection of carp (Scholz 1988). Our attempts to detect $K$. sinensis larvae in members of the genus Limnodrilus yielded negative results in spite of the large number (8661) of the specimens examined. Likewise Ily u s hin a (1987) examining tubificids from Byelorussian ponds found $K$. sinensis larval stages only in T. tubifex but not in the second dominant species, Limnodrilus hoffmeisteri. In her study, however, T. tubifex was the most frequently found species, whereas in the pond Dražský Skaličany T. tubifex is relatively rare. Thus our results are at variance with the conclusions of Kuchinska (1972) according to whom the intermediate host of $K$. sinensis is generally one of the dominant tubificid species in the respective locality.

$T$. tubifex has been described as a suitable intermediate host of $K$. sinensis under both experimental and natural conditions (Kulakovskaya 1963, Sapozhnikov 1972 , Demshin and Dvoryadkin 1980). Of interest is the absence of $K$. sinensis larvae from L. udekemianus and L. hoffmeisteri in the pond Dražský Skaličany considering that the two species have been reported as experimental intermediate hosts of $K$. sinensis (Kulakovskaya 1963). In the present study, however, only very few specimens of $L$. udekemianus were examined. Considering this fact and the results of our previous experiments (Scholz 1988) where this species appeared to be a suitable intermediate host of $K$. sinensis its possible, though presumably only minor, role in the circulation of $K$. sinensis in the locality under study cannot be entirely excluded. As to species Limnodrilus (L. hoffmeisteri, L. helveticus and L. clapardeanus), however, the numbers of the specimens examined in our study were sufficient to allow us to exclude them, with reasonable probability, as intermediate hosts of $K$. sinensis in the pond Dražský Skaličany. Moreover, neither of these species became infected in our previous attempts at experimental infection with $K$. sinensis oncospheres (S cholz 1988). However, the resolution of the question of the species specificity of $K$. sinensis to the species of intermediate host in our conditions requires besides experiments further observations on larval stages from the field. In the present study tubificids of the species $T$. tubifex and members of the genus Limnodrilus were found throughout the observation period (from May 1987 to June 1988), i. e., also in mud samples collected from the bottom of the pond Dražský Skaličany after it was drained, i. e., from November 1987 to mid February 1988. Whereas the number of tubificids of the genus Limnodrilus was large after the pond was drained, the number of $T$. tubifex specimens showed a distinct decrease during this period. However, the percentage of infected T. tubifex as well as the number of $K$. sinensis larvae including infective procercoids during the afore mentioned period were considerable (11 to $17 \%$; 68 larvae from 5 collections). Our findings therefore confirm the hypothesis of Kulakovskaya et al. (1955) that $K$. sinensis larval stages can overwinter in tubificids even in mud at the bottom of drained ponds.

The liming of the pond Dražský Skaličany with quicklime in mid Februray 1988 had a very marked effect: all mud samples collected from the bottom of the pond contained lime residues and remnants of dead chironomid and tubificid larvae till the end of spring. In spite of their survival in deeper layers of the bottom 
chironomid larvae and particularly tubificid larvae of the species T. tubifex decreased markedly in number during this period. It is primarily this considerable decrease in $T$. tubifex numbers in the samples that can account for the fact that except $4 \mathrm{~K}$. sinensis larvae found in 2 tubificids at the end of March no other larvae of the parasite were recovered from the intermediate hosts. The afore mentioned solitary finding of $K$. sinensis larvae originated from a collection containing 82 T. tubifex, whereas in the other samples collected from February to June the numbers of T. tubifex did not exceed 11 specimens. In spite of the marked decrease in intermediate hosts after the pond bottom was limed at least a small of $K$. sinensis larvae survived till the spring months and became the source of infection for new stock fish in the following year. This view is supported by the findings of juvenile $K$. sinensis in the carp examined in June and July 1988.

Although $K$. sinensis were found in all portions of the carp gut examined the pattern of their distribution was far from uniform. The predilection site of $K$. sinensis location was the proximal half of the gut, particularly its anterior "widened" portion. These observations are in keeping with our previous findings in most carp examined in other localities (S cholz 1988) and are also in harmony, except one report (Jara and Szerow 1981), with the bulk of published evidence (Murai and Monár 1975, Prouza 1981, a. o.).

Our results confirmed the important role of tubificids as intermediate hosts of $K$. sinensis and particularly as a source of infection for new stock fish because of their capability to overwinter at the bottom of drained ponds and survive, though to a limited extent, the disinfection of the bottom with quicklime. The findings reported here also showed the value of veterinary measures preventing the spread of $K$. sinensis to new localities.

\section{Zivotní cyklus tasemnice Khawia sinensis Hsü, 1935, parazita kapra, v rybníce Dražský Skaličany u Blatné}

Na základě vyšetření 280 kusů násady kapra (Cyprinus carpio - $\mathrm{K}_{1-2}$ ) a 9671 jedince vodních máloštětinatců (Oligochaeta: Tubificidae a Naididae) z rybníka Dražský Skaličany u Blatné byl od května 1987 do července 1988 sledován životní cyklus tasemnice Khawia sinensis. Výsledky ukázaly celoroční výskyt parazita $\mathrm{s}$ nejvyšším napadením kaprů na konci jara (květen) následovaný postupným odchodem především gravidních jedinců $\mathrm{z}$ hostitelů na konci června a začátku července. Od poloviny července docházelo $k$ reinvazím ryb. Tasemnice $s$ vajičky byly nalézány po celou dobu sledování. Provedení dehelmintizace sice vedlo ke snižení počtu napadených kaprů, ale $\mathrm{v}$ důsledku reinvazí se jejich počet již během měsíce opět zvýšil. Poprvé v Československu byl v přírodních podmínkách zjištěn mezihostitel tasemnice $K$. sinensis. Na sledované lokalitě je jím (pravděpodobně výhradně) nitěnka Tubifex tubifex, která v rybníce nepředstavuje dominantní druh ve srovnání se zástupci rodu Limnodrilus. Larvální stadia parazita jsou schopna přeživat $\mathrm{v}$ mezihostitelích i přes zimní období v době vypuštění rybníka a vymrznutí jeho dna. Provedení dezinfekce dna rybníka páleným vápnem po jeho napuštění sice velmi silně snížilo početnost nitěnek $T$. tubifex, ale malá část populace larev tasemnice $\mathrm{v}$ těchto mezihostitelích přežila a na jaře se stala zdrojem nákazy pro novou rybí obsádku. 


\section{Жизненный цикп цестоды Khawia sinensis Hsü, 1935, паразита карпа, в прүду Дражски-Скаличани близ Блатной}

Исходя из исследования 280 посадочных карпов (Cyprinus carpio - $\mathrm{K}_{1-2}$ ) и 9671 особи малощетинковых червей (Oligochaeta: Tubificidae и Naididae) пруда Дражански-Скаличани близ Блатной, с мая 1987 г. по июль 1988 г., проводили наблюдения жизненного цикла цестоды Khawia sinensis. Результаты выявили круглогодичное наличие паразита с максимальным заражением карпов в конце весны (май) с последующим постепенным выходом прежде всего осемененных особей из хозяев в конце июня и в начале июля. С половины июля наблюдалась реинвазия рыб. Цестод с яичками находили в течение всего наблюдаемого периода. Хотя и выполненная дегельментизация привела к понижению численности зараженных карпов, однако в результате реинвазии их численность вновь увеличилась уже в течение одного месяца. В Чехословакии был в естественных үсловиях впервые выявлен промежүточный хозяин цестоды $K$. sinensis. В исследуемом пруду упомянутым промежуточным хозяином является (по всей вероятности исключительно) Tubifex tubifex, не представляющий доминирующий вид по сравнению с представителями рода Limnodrilus. Личинки паразита в состоянии выживать в промежүточных хозяевах в течение зимнего периода, т. е. в период, когда выпускают воду из пруда и его дно вымерзает. Дезинфекция днища пруда жженой известью после его наполнения водой хотя и сүщественно понизила численность T.tubifex, , однако небольшая часть популяции личинок солитера в упомянутых промежүточных хозяевах выжила, став весной источником заражения нового рыбопосадочного материала́.

\section{Acknowledgements}

We wish to thank Mr. Hajn, director of the branch plant of the State Fishery, and Mr. Kalousek, head of the centre Blatná, for allowing us to carry out the research. Thanks are also due to Mr. Nusl and Mr. Bláha for technical assistance.

\section{References}

DEMSHIN, N. I. -DVORYADKIN, V. A.: Biologiya Khawia sinensis Hsü, 1935 (Caryophyllidea, Cestoda) - parazita amurskogo sazana. Gidrobiol. zhurn., 16, 1980: 77-82.

HRABĔ, S.: Vodní máloštětinatci (Oligochaeta) Československa. Acta Univ. Carol.-Biol., Vol. 1979 (1-2), 1981 : 1-167.

ILYUSHINA, T. L.: Sezonnye izmeneniya czislennosti i zarazhennosti oligochet procerkoidami kaviy v prudakh razlicznogo biotekhniczeskogo naznaczeniya. Trudy GELAN, 35, 1987: 38-41.

JARA, Z. - SZEROW, D.: Zmiany histopatologiczne i lokalizacja tasiemca Khawia sinensis w jelicie karpi (Cyprinus carpio L.). Wiad. Parazytol., 27, 1981: 693-703.

KENNEDY, C. R.: Tubificid oligochaetes as food of coarse fish. Proc. IV British Course Fish Conf., Liverpoool Univ., 27-28th March, 1969.

KULAKOVSKAYA, O. P.: $\mathrm{K}$ biologii $\mathrm{i}$ rasprostraneniyu gvozdicznika Khavia sinensis Hsü, 1935. Problemy parazitologii, 2, 1963: 200-205.

KULAKOVSKAYA, O. P. - KROTAS, R. A.: O Khavia sinensis Hsü (Caryophyllaeidae, Cestoda) - parazite, zavezennom s Dalnego Vostoka v karpovye khozyaystva zapadnych oblastey SSSR. Doklady AN SSSR, 137, 1961: $1253-1255$.

KULAKOVSKAYA, O. P. - KUPCZINSKAYA, O. S.-YALINSKAYA, N. S.: Faktory opredelyayushczie zarazhennost ryb gvozdicznikami v rybnykh khozyaystvach Lvovskoy oblasti. Parazity i parazitozy czeloveka i zhivotnykh, Naukova Dumka, Kijev, 1965: 256-263. 
KUPCZINSKAYA, O. S.: Oligokhety zapadnykh oblastey Ukrainy i ikh rol v razvitii nekotorykh cestod. Tr. Vsesoyuz. Gidrobiol. obshcz., 17, 1972: 125-133. (Cited after Iluyshina 1987).

LOZINSKA-GABSKA, M.: Biologia i dzialane patogenne Bothriocephalus gowkongensis Yeh, 1955 i Khawia sinensis Hsü, 1935. Wiad. Parazytol., 27, 1981: 685-694.

MARGOLIS, L.-ESCH, G. W.-HOLMES, J. C.-KURIS, A. M.-SCHAD, G. A.: The use of ecological terms in parasitology (report of an HOC committee of the American Society of Parasitologist). J. Parasitol., 68, 1982: 131-133

MURAI, É. - MOLNÁR, K.: Caryophyllaeus fimbriceps Annenkova-Chlopina, 1919 and Khawia sinensis Hsü, 1935: Occurrence in Hungary and Morphology. Parasitol. Hung., 8, 1975: 63-70.

PROUZA, A.: Khawióza kaprů. Veterinářství, 32, 1982: 470-472.

PROUZA, A. - TESARČf́, J.: Khawióza kaprư. Čs. rybníkářství, 1, 1977: 11-13.

SAPOZHNIKOV, G. I.: Sezonnaya i vzroastnaya dinamika kavioza karpov v Moskovskoy oblasti. Byul. VIGIS, 4, 1970: 117-119.

SAPOZHNIKOV, G. I.: Vliyanie kaviy na rost i upitannost karpov. Byul. VIGIS, 5, 1971 : 89-94.

SAPOZHNIKOV, G. I.: K biologii vozbuditela kavioza karpov. Byul. VIGIS, 7, 1972: 31-35.

SCHOLZ, T.: Tasemnice ryb Ceskoslovenska a biologie některých druhů. PhDr. Thesis. Parazitologický ústav ČSAV, České Budějovice, 1988.

SHCZERBAN, N. I.: Cestodozy karpov. Urozhay, Kijev, 1965, 80 pp.

TESARĆfK, J.-PROUZA, A.: Úspě̌̌ná léčba kaviózy Taenifuginem. Bul. VÚRH Vodňany, 4, 1977: $26-31$. 